PressAcademia

www.pressacademia.org/journals/jmml
JMML

ISSN 2148-6670

Journal of Management, Marketing and Logistics

YEAR 2019 VOLUME 6 ISSUE 1

\title{
INDIVIDUAL ENTREPRENEURIAL ORIENTATION AND GRADUATE BUSINESS PERFORMANCE OF THE UNIVERSITY OF SRI JAYEWARDENEPURA IN SRI LANKA
}

\author{
DOI: 10.17261/Pressacademia.2019.1033 \\ JMML- V.6-ISS.1-2019(5)-p.44-61 \\ ${ }^{1}$ Management \& Science University, Shah Alam, Malaysia. \\ hksri@sjp.ac.lk, ORCID: 0000-0002-7205-4783 \\ ${ }^{2}$ Management \& Science University, Shah Alam, Malaysia. \\ shukri@msu.edu.my \\ ${ }^{3}$ Management \& Science University, Shah Alam, Malaysia. \\ alik@msu.edu.my \\ ${ }^{4}$ Management \& Science University, Shah Alam, Malaysia. \\ drferdous@msu.edu.my
}

Hewa Kumbalgoda Gamage Sriyani Ranasinghe ${ }^{1}$, Mohd Shukri Abd. Yajid², Ali Khatibi ${ }^{3}$, S. M. Ferdous Azam ${ }^{4}$

Date Received: September 13, 2018

Date Accepted: February 20, 2019

To cite this document

Ranasinghe, H. K. G. S., Yajid, M. S. A. Y., Khatibi, A., Azam, S. M. F. (2019). Individual entrepreneurial orientation and graduate business performance of the University of Sri Jayewardenepura in Sri Lanka. Journal of Management, Marketing and Logistics (JMML), V.6(1), p.44-61.

Permemant link to this document: $\underline{h t t p: / / d o i . o r g / 10.17261 / P r e s s a c a d e m i a .2019 .1033 ~}$

Copyright: Published by PressAcademia and limited licenced re-use rights only.

\begin{abstract} reliability and the SEM with PLS used for the analysis. Capability (0.264) and Risk-taking (0.062). insignificant result.

Keywords: Entrepreneurial orientation, graduate entrepreneur, business performance, university system. JEL Codes: A23, C12, 123
\end{abstract}

Purpose - Entrepreneurship Orientation is an emerging trend that has attracted much attention presently. This study attempts to examine the relationship between individual Entrepreneurship Orientation and Business Performance among graduate entrepreneurs in the University of Sri Jayewardenepura in Sri Lanka. It is the special intension of this research, to explore this relationship within the context of different theories, models and approaches such as Entrepreneurship Theories, Theory of Planned Behaviour (TPB), Lumpkin and Dess Model and Taatila Model.

Methodology - Data collection was done using 109 samples through a questionnaire. The means of descriptive statistics, tests of validity,

Findings - The relationships between BP and Entrepreneurship Desire were (0.163), Innovativeness (0.255), Proactiveness (0.318), Networking

Conclusion - The relationship between individual EO for the four dimensions and BP is significant and positive while Risk-taking showed the

\section{INTRODUCTION}

Harmonizing entrepreneurial orientation (EO) with graduate entrepreneurs' behaviour is an intentional process in converting talents into Business Performance (BP). The subject of EO has become the centre of attraction and created a greater interest than ever in research and development of entrepreneurship. It is evident that there exist different types of entrepreneurship research that focuses on contemporary markets of business creation, grab market share and acquire the customers' assets along with the employees of unobtrusive current businesses (Lackeus, 2018). The contributors of a large number of publications to this field are the persons who showed an interest and focused on conscientious search in the appropriate variations within different countries. However, few empirical studies have been identified among these publications of those countries (Duru, Ehidiamhen \& Chijioke, 2018; Kaunda, 2012; Lumpkin \& Dess, 2006; Sriprasert, 2013; Wiklund \& Shepherd, 2005). It is noteworthy to observe the greater attention given to business research and practical development in social sciences at present 
(Kraus, Burtscher, Vallaster \& Angerer, 2018; Memon, Ting, Ramayah, Chuah \& Cheah, 2017). Besides, a few published doctoral dissertations serve as exceptions to the small number of empirical studies that have been done in the field of EO and BP under different disciplines in the research (Al-Ansari, 2014; Haid, 2004; Harms, 2004; Kaunda, 2012; Ofem, 2014). This scenario confirms the mandatory requirement of entrepreneurship for the sustainability of any country (Lomberg, Urbig, Stockmann, Marino \& Dickson, 2017; Sok, Snell, Lee, \& Sok, 2017) the fact that EO enhances using available knowledge to improve BP (Weerakoon, 2014). Nevertheless, the limited study outcomes available cannot be used to generalise the practical consequence of EO and its input to BP in different contexts that include developing countries in the world.

EO is recognized as an essential competency required to become an entrepreneur and deal with BP (Koe, 2016) and further it articulates the view that the successful EO should concentrate on corporate entrepreneurial behaviours of the members within an organization who practices creativity, innovativeness, capability and the skill to perform tasks and solve problems (Haider, Asad \& Fatima, 2017).

It is believed that the best method to measure activity or process of carrying out a function successfully in order to find the efficiency and effectiveness of the business during a given time span, is BP (Raimond, 2016). Further, there is a mounting amount of proof to indicate that businesses dealing with increased data collection and analysis, along with goal setting and human resource practices focus on performance show higher productivity while achieving greater heights of output growth when compared with ventures that practice few formal management processes (Forth \& Bryson, 2018). Although this substantiation is demonstrated at a higher level in manufacturing industries and as a result of the vast number of recent studies carried out in this field, it is spreading for service industries as well.

This article intends to investigate the association between individual EO and graduate entrepreneurs' BP in different disciplines which would direct to future studies based on the input of the SMEs sector in any part of the world. The objective of this article is to investigate how individual dimensions of entrepreneurial orientation impact over business performance among graduate entrepreneurs of University of Sri Jayewardenepura (USJ), Sri Lanka. This article is focused on the importance of each dimension of $\mathrm{EO}$ and considers the following questions:

(1) What is the impact of Entrepreneurship Desire over the Business Performance among graduate entrepreneurs of the University of Sri Jayewardenepura?

(2) What is the impact of Innovativeness over the Business Performance among graduate entrepreneurs of the University of Sri Jayewardenepura?

(3) What is the impact of Proactiveness over the Business Performance among graduate entrepreneurs of the University of Sri Jayewardenepura?

(4) What is the impact of Risk-taking over the Business Performance among graduate entrepreneurs of the University of Sri Jayewardenepura?

(5) What is the impact of Networking Capability over the Business Performance among graduate entrepreneurs of the University of Sri Jayewardenepura?

Many difficulties and failures faced by the graduate entrepreneurs in running their businesses could become difficult issues in the present unless greater attention is given to EO. Graduate entrepreneurs are keen to acquire appropriate knowledge which could be applied to the advantage of their businesses. The tactical nature of entrepreneurs' attitude to learning in order to have a unique EO atmosphere which demonstrates entrepreneurial behaviour is essential. Hypothetically, the theories of EO are associated with creating an internal entrepreneurial environment, which allows having entrepreneurial processes, practices and decision-making activities through business strategies of organization (Covin, Green, \& Slevin 2006; Lumpkin \& Desss, 2006; Rauch et al., 2009). The dimension of EO are the behaviors exhibited in business strategy as all these actions are linked to individual entrepreneurial traits, attitudes and behaviors (Bolton \& Lane, 2012; (Covin, Green \& Slevin, 2006; Lumpkin \& Dess, 2008). Hence, EO is considered a critical talent required for being an entrepreneur in order to manage a business with a successful performance. A positive relationship was discovered between EO and entrepreneurial intention to BP (Bolton \& Lane, 2012; Ekpe \& Mat, 2012; Ibrahim \& Lucky, 2014), and similar links to EO dimensions such as risk-taking and innovativeness (Robinson \& Stubberud, 2014), pro-activeness and risk-taking (Kropp, Lindsay \& Shoham, 2008) have also indicated to affect business start-up intention. Also, it is also noteworthy that EO positively affects BP (Gupta \& Batra,2015; Koe \& Majid, 2013). However, it is essential to understand that two different levels can be used to measure EO at the business level and individual level (Elenurm, 2012). 
Nevertheless, a scarcity of studies examining EO at individual level exists, as current literature on EO mainly focus on a business level. The importance of examining EO at the individual level is significant as it is connected to the individual's decisions that affect BP. The shortage of studies on EO at an individual-level dimension (Goktan \& Gupta, 2015) is an issue of concern and studies that deal with individual EO are still limited (Bolton, 2012; Kollmann, Christofor \& Kuckertz, 2007; Lee, Lim \& Pathak, 2011).

The government of Sri Lanka is not backward in the surge of entrepreneurship expansion within the country by elevating the dissemination position of the university education system in the attempt of distributing knowledge. For instance, the creation of graduate entrepreneurial businesses to assist entrepreneurial individuals as a contribution to meet the gap of the national income and the employment generation of the country, considering global changes, was implemented by the University Grant Commission (UGC) of Sri Lanka. Annually around 26,000 graduate intellectuals are produced by the 15 state universities and postgraduate along with other institutes in Sri Lanka, towards its journey leading to a knowledge-based universal economy (UGC annual report, 2017).

However, the university graduates still possess the mindset of being employed rather than opening their business ventures, and the entrepreneurial culture needs to be cultivated. Furthermore, higher education continuously confronts issues like lack of interest among university graduates to become entrepreneurs and lack of involvement with non-business disciplines (Hamidon, 2012). Despite the efforts taken so far to promote entrepreneurship culture, the number of graduate entrepreneurs in the university system of Sri Lanka has not yet reached a satisfactory level. _Since, currently, there is no proper EO system agreed upon, in the university system that would ensure the success of graduate businesses, as exposed by literature (Wedathanthrige, 2014), the question about this background was formulated. The importance of examining how the graduate entrepreneurs could overcome the existing issues about their businesses by way of best practices within the individual EO system is evident (Buckley \& Park, 2014; Fani, 2015). Hence, the question arises as to how the individual entrepreneurial orientation impacts on business performance and to what extent does it have an impact on BP of graduate entrepreneurs in USJ of Sri Lanka.

\section{LITERATURE REVIEW}

Entrepreneurs have to deal with diverse, unknown and unpredictable challenges simultaneously with their orientations. Hence, it is evident from the literature that during a substantial period, different theories, approaches, perspectives and models were used in measuring EO. As theories of entrepreneurship point out that entrepreneurs can be considered as crucial transformer of economic development, and they are model personalities of the society but not tremendous normal individuals (Lomberg, Urbig, Stockmann, Marino \& Dickson, 2017; Mahmood \& Hanafi, 2013; Sok, Snell, Lee, \& Sok, 2017). Contingency approach suggests the effect of different issues about EO and appropriate behavioural styles for successful performance of the venture within a professional standard in numerous perspectives.

Further, some entrepreneurial points of view state as to how the relationship of the specific fields affect and others mainly consider the adequate position of entrepreneurship. This article is based on the theoretical view interpreted by Lumpkin and Dess model while driving the empirical attention for specific dimensions of EO (Kaunda, 2012). Besides, modified multidimensional view of dimensions of EO is distinguished namely Entrepreneurial Desire, Innovativeness, Pro-activeness, Risktaking and Networking Capability (Taatila, 2012) which undoubtedly led to the formulation of the model depicted in this article.

The significance of the above dimensions of EO was indicated further by the intention of the entrepreneur, in dealing with some entrepreneurial characteristics and behaviours. As per the literature survey, Theory of Planned Behaviour (TBP) is the basis for the theoretical approach and EO activity in entrepreneurial intention (Ajzen, 2001). It is also noteworthy that TPB has been ignored in the field of entrepreneurship research while numerous other disciplines have extensively made use of this theory in carrying out their research (Krueger \& Carsrud, 1993). Almost all theories have examined the entrepreneur and entrepreneurship by their perception, and hence, these can only provide a restricted view of the entrepreneurial phenomenon, and there is no view which can be identified as right or wrong. It is essential to conquering this problematic situation for the sustainable development of the country (Lomberg, Urbig, Stockmann, Marino \& Dickson, 2017; Sok, Snell, Lee, \& Sok, 2017), which is the main aim of this exercise.

Based on the sound literature review, EO is a critical dimension that reflects some of the processes which are of interest to this article and considered as relevant for the completeness. Formerly, EO was regarded as a concept which comprises three dimensions such as innovativeness, pro-activeness and risk-taking (Miller, 1983). After that, these three dimensions were categorized as unidimensional construct known as entrepreneurial strategic posture (ESP), which was identified as essential for successful BP in threatening environments (Covin \& Slevin, 1989). Further, this EO concept was recognized as a multidimensional construct that is made up of five prominent independent dimensions identified to be autonomy, 
innovativeness, risk-taking, pro-activeness and competitive aggressiveness (Lumpkin \& Dess, 1996). After that, an empirical study was conducted using these five dimensions to investigate the relationship between EO and BP (Kaunda, 2012). Subsequently, there were further suggestions of using different dimensions of EO to investigate the relationship between EO and BP.

The prime importance of Entrepreneurial Desire, Innovativeness, Proactiveness, Risk-taking and Networking capability dimensions of EO in dealing with entrepreneurial characteristics was shown by many studies (Hanafiah, Yousaf \& Hashim, 2016; Taatila, 2012). Entrepreneurial Desire is the craving for independence about entrepreneurship, which is an essential inspiration for entrepreneurial business (Hanafiah, Yousaf \& Hashim, 2016). It is also explained as the common denominator which is exhibited as a potent force by entrepreneurs. Two types of entrepreneurial desires are shown where one is the entrepreneur and the other is to attain something entrepreneurial. However, the difference is that the former focuses on gaining achievement although both may lead to success. A study conducted using a sample of 211 from Kuwait revealed that desire is a stronger predictor of growth-oriented intentions when compared with the income-substitution intentions. Further, the entrepreneurial desire was also found to partially mediate the effects of attitude, anticipated emotions and entrepreneurial intentions (Riquelme \& Al Lanqawi, 2016).

Innovativeness is explained as the methods through which businesses recognize new opportunities, and it is also known as the ability to engage in new business ideas to deliver new processes and actions to generate new solutions to problems in the business, and considered as a significant constituent of EO (Ofem, 2014). Using a sample of 284, a study was carried out in Malaysia which proved that there is a significant relationship between product innovation and BP where the product has a stronger effect of that of the services. Therefore innovativeness is considered as an essential component for SMEs and policymakers in the current entrepreneurial processes (Rasli, 2013).

Proactiveness can be explained as the activities of the businesses with a futuristic viewpoint to avoid problems, requirements and changes to grasp new business opportunities (Kropp, Lindsay, \& Shoham, 2008 as cited in Omisakin, Nakhid, Littrel, \& Verbitsky, 2016). An empirical research study done in Pakistan using 384 companies to investigate the Entrepreneurial Orientation and Business Performance of Manufacturing Sector Small and Medium Scale Enterprises of Punjab, Pakistan revealed that proactiveness has a significant impact over BP of manufacturing sector SMEs. (Haider, Asad, Fatima \& Abidin, 2017)

Risk-taking is described as the eagerness of the businesses to change from the original business undertaking into the unfamiliar area (Chua, 2014; Perz-Luno et al., 2011as cited Ejdys, 2016). The greater insecurity present in the internal and external business environments indicates the consequences of risk-taking (Karyotakis \& Moustakis, 2016). A study conducted on the Effect of Entrepreneurial Orientation on Business Performance. Respondents 153 of the embroidery SMEs in Indonesia resulted in showing that risk-taking EO significantly affected BP.

The final dimension of networking capability refers to the direct procedures and methods vital to have access to new competence and resources for the business in order to overcome competitiveness (Taatila, 2012). A research study carried out in Ghana on Entrepreneurial orientation, market orientation (MO), network ties, and performance revealed that having high levels of $\mathrm{EO}$ and $\mathrm{MO}$ improves $\mathrm{BP}$ and it is conspicuous when there are sufficient social and business network ties where the performance benefits arising out of EO and MO are greatest ( Boso, Story, Cadogan 2013). The five dimensions of EO have been explained above, relevant to this study. Next section describes the other central dependent construct of this article which is BP.

BP was considered as the dependent variable of the study based on which this article is presented. Efficiency, effectiveness and economic efficiency (Bocskei \& Fekete, 2012; Neely, Gregory \& Platts; 1995, Rolstad, 1995) are the most common denominator used for defining BP by many researchers as pointed out in national and international literature. It is noteworthy to mention that items such as value creating, quality, productivity, innovation and changing ability provides a complementary task. Some researchers describe BP as an achievement of a task which is measured on comparing with a preset known value of accuracy, totality, expenditure, and the pace of accomplishing the financial and non-financial outcome of the business (Hudson et al., 2001). As the next step, it is intended to submit a review of the past and present research along with BP theories. The use of single performance indicators to measure BP might result in biased output as BP has a multidimensional nature. Therefore it is clear from previous studies that different instruments were used as an alternative for BP (Engstrom, 2016). Generally, economic perspectives are used to measure BP in small businesses (Migiro, 2014).

Nevertheless, the results of entrepreneurship reach further than economic aspects which necessitate investigating the social wealth features or contribution to the society (Venkataraman, 1987) resulting from entrepreneurship not only financial wealth creation. It is vital to observe that personal contentment is considered as a significant incentive obtained from entrepreneurship 
which is achieved by the process of generating value by having dedicated time, effort and resources along with financial gains (Kaplan \& Norton, 2010; Rauch et al., 2009). Another view expresses that spiritual aspects are the main success factors for businesses but not measured by financial perspectives (King \& Roerts, 1987). Elements that generate value in the form of looking at shareholders, customer perception, excellent internal business processes, learning and growth features are regarded as a non-financial perspective which is a comprehensive framework (Salehia \& Ghorbanib, 2011).

It is evident that there are many diverse methods to measure BP of ventures. Specialists and other persons with numerous interests examine this notion in various angles. Literature provides proof that Goal Approach and System approach are theoretical frameworks that assist measuring the efficiency in assessing the use of resources in a business. Besides, it is noted that in the Sri Lankan context BP measurements are being done using traditional and new methods (Zsido \& Fenyves, 2015).

Traditional performance measures cannot be used for measuring the changes that occur in the competitive environment and plans of existing businesses which require different application methods (Zsido \& Fenyves, 2015). During the mid-1980s, theories and scientific investigations proved that sustainable progress and continued existence of a business is challenging to reach only by focusing on the shareholder value. It was noted that several stakeholders exist in businesses, which make it crucial to allocate their importance as well (Donaldson \& Preston, 1995; Clarkson, 1995). A stakeholder is an individual who could manipulate activities directing to the achievement of organizational objectives or a person who is a part of it (Freeman and Reed, 1983). The image of the business venture which is determined by the social changes and other social views that came forward are connected with the stakeholder theory in no small extent. Therefore, various methods of measurements are used by different business ventures in evaluating BP, and the choice is based on the type of processes of the business (Zsido \& Fenyves, 2015).

Different instruments have been used to measure BP depending on the intention of the business as its multidimensional nature makes it difficult to find a single model to assess BP of SMEs individually (Gerba \& Viswanadham, 2016). It is demonstrated that investigating the consequences of EO have been used in much empirical research carried out on the BP concept. These empirical research (Refer: Annex 2.6) have been divided into precise areas such as present discussion areas, theory and research application along with countries where research was conducted (Beliaeva, 2014).

An empirical study based on the financial literacy and BP in free economy businesses in Ecuador were done with a sample of 750 microenterprises, and the outcome showed that both financial literacy and role models are vital in assessing BP for some but not all (Engstrom, 2016). The results of another study conducted in the USA using a sample of 300 new ventures revealed that the definite link between EO and new BP is affected by political networking in a negative moderating manner while financial networking showed a reverted U-shaped connection and at the same time business networking indicating a definite link. These findings enhance the knowledge on the effect of managerial networking on the performance about EO in new ventures, and it also signifies the use of EO and various types of managerial networking in new businesses to increase the progress in the changing economy in China (Wang, 2008).

\subsection{Relationship of Entrepreneurial Orientation and Business Performance}

Literature specifies that different types of perspectives have been used to indicate the impact of EO on BP. Multidimensional views of some literature indicates that EO of the business is linked with BP to a higher level and many academics focused their attention on this relationship (Filser \& Eggers, 2014; Schepers, Voordeckers, Steijvers \& Laveren, 2014; Shehu \& Mahmood, 2014 as cited in Shogren, 2017) envisaging that an increased level of EO results enhanced performance (Al-Nuiami, Idris, AlFerokh \& Hussein, 2014; Schepers, Voordeckers, Steijvers \& Laveren, 2014; Van Doorn, Jansen, Van den Bosch \& Volberda, 2013; Vij \& Bedi, 2012). Further, this view indicating a positive relationship between EO and BP is accepted by many other researchers (Alarape, 2013; Laukkanen, Nagy, Hirvonen, Reijonen \& Pasanen, 2013; Wiklund \& Shepherd, 2005).

Another empirical study done in South Africa on entrepreneurial orientation which is a case of Gauteng province with a sample of 500 SMEs revealed that EO has a long, significant relationship with BP (Radipere, 2015). Another study done in Malaysia using 209 big family businesses revealed that owners demonstrated risk-taking while innovativeness was common among big family businesses (Arham, 2014). EO indicated a positive relationship with BP and marketing competencies as found by a similar research study conducted using 599 small businesses in the USA too. Further, a study executed in Portugal with 168 small ventures proved that businesses were active in demonstrating innovativeness, risk-taking and proactiveness (Azevedo, 2008). Likewise, a study done using 181 big businesses in the US, found that EO has a positive relationship with BP while EO contributes to business growth (Hult, Hurley \& Knight, 2004). Based on the above discussion the present study envisages the significant impact EO has on $\mathrm{BP}$, and this relationship between EO and BP is the central theme in this study. 


\section{DATA AND METHODOLOGY}

The research procedure leads the research strategy and the research instruments in order to set the research objectives and research questions. Further, a synopsis of the methods that are used to examine the research problem is provided by the researcher who is regarded as the main focal point of this study. This section intends to highlight how and to what extent EO affects BP. During the investigation, the measuring was done using 34 indicators for EO and 18 indicators for BP. Structured Survey Questionnaire method (SSQ) was taken as the prominent data collection method. The respondents' attentiveness of EO and BP were obtained through this questionnaire which was the survey instrument. The sample consisted of 109 graduate entrepreneurs of the USJ which is the universal sample, and the unit of analysis was the individual graduate entrepreneurs of USJ who manage their businesses after obtaining the first entrepreneurship degree. SPSS and Structural Equation Modeling (SEM) technique with Smart Partial Least Squares (PLS) were employed to analyze the collected data.

\subsection{Proposed Conceptual Model}

Based on the objectives and research problem of this article, the proposed conceptual framework was formulated using the popular models and approaches (Taatila, 2012; Kaunda, 2012; Lumpkin \& Dess, 1996). This proposed conceptual model applicable to the specific research question in this article was developed after a scrupulous examination of the selected dimensions and associations surfaced through the literature review with the most up to date information (Omisakin, Nakhid, Littrell, \& Verbitsky, 2016; Radipere, 2015). Mainly the Theory of Planned Behavior (TPB), contingency theory and the model of Lumpkin and Dess as well as the EO dimensions relevant to the graduate entrepreneurs were given priority in developing the proposed conceptual framework for this study. Consequently, the study focused on two main variables based on the conceptual framework and 7 dimensions along with the 52 indicators in the analysis which were not examined in a single model in the past empirical research. EO is mostly considered as an independent variable (Beliaeva, 2014; Lumpkin \& Dess, 1996; Taatila, 2012;), while BP was used as a dependent variable (Kaunda, 2012; Omisakin, Nakhid, Littrell, \& Verbitsky, 2016; Radipere, 2015) regarding literature. Accordingly, the primary variable of this present study to is EO which behaves in the form of an independent variable in the theoretical framework. The five dimensions of EO selected were Entrepreneurship Desire, Innovativeness, Proactiveness, Risk-taking and Networking capability. Financial and non-financial measurements were the two main dimensions of the dependent variable, BP. The conceptual framework that was established in order to answer the research questions is illustrated in Figure 1 below.

Figure 1: Proposed Conceptual Framework

Independent Variable
Dependent

Variable

\begin{tabular}{|c|c|c|}
\hline $\begin{array}{l}\text { Entrepreneurial } \\
\text { Orientation }\end{array}$ & \multirow{2}{*}{$\mathrm{H}_{1}$} & \multirow[t]{3}{*}{$\begin{array}{c}\text { Business } \\
\text { Performance }\end{array}$} \\
\hline \multirow{2}{*}{$\begin{array}{l}\text { Entrepreneurship } \\
\text { desire }\end{array}$} & & \\
\hline & $\mathrm{H}_{2}$ & \\
\hline Innovativeness & \multirow{2}{*}{$\mathrm{H}_{3}$} & \multirow{5}{*}{$\begin{array}{c}\text { Finance } \\
\text { Non-Finance }\end{array}$} \\
\hline \multirow{2}{*}{ Proactiveness } & & \\
\hline & $\mathbf{H}_{4}$ & \\
\hline Risk-taking & & \\
\hline Networking capability & $\mathrm{H}_{5}$ & \\
\hline
\end{tabular}


EO consisting of its five dimensions (Taatila, 2012; Kaunda, 2012; Lumpking \& Dess, 2001) along with BP having its two dimensions (Botchkarev, 2015; Paalic \& Busattic, 2015) were shown in the above relationship whereas these variables have never been tested earlier in a single model to examine the link between EO and BP.

This unique model explains how the proposed framework is applied for graduate entrepreneurs who run their businesses in the university environment. It is anticipated that it could be integrated into UGC policy framework, in order to trim down social conflicts resulting from unemployment, expand the infrastructure and to create a university contribution to increasing the national level consciousness by promoting entrepreneurial culture in Sri Lanka. Consequently, this framework grants risk-taking opportunities with more worthwhile diversified investments in the graduate entrepreneurial businesses that suggest attaining BP through EO as the output of this study.

\subsection{Research Hypotheses}

The hypotheses are formulated for this research study according to the relationships shown in the theoretical framework. The probable relationships between the two variables of EO and BP as shown by the proposed model arose from theory-based evidence emerging from the literature survey which served as the foundation to the conceptual framework, and it authenticates these links between variables. By the conceptual framework following hypothesis have been developed in the study for empirical testing:

H1: Entrepreneurship Desire has a significant impact over the Business Performance among graduate entrepreneurs of University of Sri Jayewardenepura, Sri Lanka.

H2: Innovativeness has a significant impact over the Business Performance among graduate entrepreneurs of University of Sri Jayewardenepura, Sri Lanka.

H3: Proactiveness has a significant impact over the Business Performance among graduate entrepreneurs of University of Sri Jayewardenepura, Sri Lanka.

H4: Risk Taking has a significant impact over the Business Performance among graduate entrepreneurs of University of Sri Jayewardenepura, Sri Lanka.

H5: Networking Capability has a significant impact over the Business Performance among graduate entrepreneurs of University of Sri Jayewardenepura, Sri Lanka.

\subsection{Types of Data}

Data collection and analysis were planned with systematic tools and techniques using most relevant analytical methods. The procedure of data collection was planned to give a great deal of consideration to the facts such as the exact data, the method of data collection, and the data collection process (Sekaran \& Bougie, 2013).

\subsection{Test Procedures for Instrument Development}

The stages of testing a thesis for the reliability and validity measurements of the instrument are Pre-test, Pilot-test and Final test. Several statistical techniques are used for these stages of measurement of data for these different tests.

\section{FINDINGS AND DISCUSSIONS}

The primary objective of this article is to analyze relevant data to examine the relationship between Individual EO and BP among graduate entrepreneurs in the USJ in Sri Lanka. Data collection was conducted by distributing a structured questionnaire among 109 graduate entrepreneurs of USJ. The Software Package of Social Sciences (SPSS- version 23) and Structural Equation Modeling (SEM) using Smart-PLS path modeling techniques were used to analyze the data. The hypotheses were tested by quantitative analysis which helped to find the impact of dimensions of EO over the BP among graduate entrepreneurs of USJ.

The study was conducted as a cross-sectional at one point in time. The unit of analysis of this study was based on graduate entrepreneurs as individuals. Five different dimensions of EO that were selected to investigate the relationship between EO and BP are Entrepreneurship Desire, Innovativeness, Proactiveness, Risk-taking and Networking capability dimensions of EO as these have demonstrated entrepreneurial characteristics in many studies (Taatila, 2012). Entrepreneurship Desire was measured using 6 indicators, Innovativeness by 5 indicators whereas one item was deleted during the pilot test, Proactiveness by 6 indicators, Risk-taking by 6 indicators and Networking capability by 10 indicators. The dependent variable which is BP was 
assessed using financial and non-financial measurements. Accordingly, the financial dimension was measured by 8 indicators while non-financial dimension was evaluated using 10 indicators.

Five points Likert scale was applied for obtaining responses from the sample. Cronbach's Alpha assessed the reliability of the instrument while the validity of the same was evaluated by factor analysis. On receiving the completed questionnaires, initial data screening was done to obtain accurate data set for the analysis. Initially, a Pre-test was conducted to check the validity of the instrument, and the questionnaire was modified in the first instance. Secondly based on the results of the Pre-test the questionnaire was developed for the pilot test. During the pilot test 32, responses were analyzed using Cronbach's Alpha for reliability (>0.7) and Factor analysis to assess validity (>0.5); after that, final test of the analysis was carried out using 109 graduate entrepreneurs. The results of the descriptive statistics are given in Table 1 below.

Table 1: Descriptive Analysis

\begin{tabular}{lcccc}
\hline Variables & Mean & SD & Skewness & Kurtosis \\
\hline Entrepreneurship Desire & 3.482 & 0.838 & 0.278 & -0.562 \\
Innovativeness & 3.119 & 0.797 & 0.100 & -0.387 \\
Proactiveness & 3.215 & 0.713 & 0.037 & -0.452 \\
Risk-taking & 2.580 & 0.541 & -0.102 & -1.246 \\
Networking Capability & 3.102 & 0.808 & -0.017 & -0.724 \\
Business Performance & 3.047 & 0.536 & 0.128 & -0.207 \\
\hline
\end{tabular}

Note: SD: Standard Deviation

The above table indicates that the skewness of BP value was within \pm 1 which indicates that the data distribution is symmetrical. Further, it is evident that the data has a normal distribution as the values of Skewness and Kurtosis are below 3 and 8 respectively (Kline, 2015). Besides, the mean values of the variables also highlight that the level of the above variables is below average which indicates the need for more studies.

The next step is measuring construct reliability and validity using Partial Least Square in SEM. Further Average Variance Extracted (AVE) and Composite Reliability (CR) was calculated. The acceptable values for Cronbach's Alpha, AVE and CR were 0.60, 0.50 and 0.70 respectively (Gardner, 1998; Henseler \& Chin, 2010; Hair, Ringle \& Sarstedt., 2013) which ensures the reliability and validity of the instrument. The calculated Cronbach's Alpha, AVE and CR values are illustrated in table 2 below.

Table 2: Values of Cronbach's Alpha, AVE and CR for EO and BP

\begin{tabular}{lccc}
\hline Variable & Cronbach's Alpha & CR & AVE \\
\hline Entrepreneurial Orientation & & & 0.731 \\
Entrepreneurship desire & 0.926 & 0.942 & 0.755 \\
Innovativeness & 0.919 & 0.939 & 0.700 \\
Proactiveness & 0.893 & 0.921 & 0.699 \\
Risk-taking & 0.921 & 0.933 & 0.697 \\
Networking capability & 0.926 & 0.941 & 0.601 \\
Business Performance & & & 0.540 \\
$\quad$ Finance & 0.867 & 0.900 & 0.875 \\
$\quad$ Non-Finance & 0.828 & & 0.5 \\
\hline
\end{tabular}

Note: CR: Construct Reliability, AVE: Average Variances Extractions

All the measured values are above the threshold level which indicates the reliability and validity of the constructs. The next step was to calculate factor loadings to ensure discriminant validity with the assistance of Fornell Larcker criterion (Hair, Ringle \& Sarstedt., 2013). The calculated values of all the items were given in Table 3. 
Table 3: Measurement Model Values in (Reflective- $\mathbf{1}^{\text {st }}$ Order Level)

\begin{tabular}{lccrrr}
\hline Variable & CR & AVE & $\begin{array}{r}\text { Cronbach's } \\
\text { Alpha }\end{array}$ & t-Stat & p-value \\
\hline Entrepreneurship Desire & & 0.731 & 0.926 & 9.564 & 0.000 \\
Innovativeness & 0.942 & 0.755 & 0.919 & 12.092 & 0.000 \\
Proactiveness & 0.939 & 0.893 & 11.979 & 0.000 \\
Risk-taking & 0.921 & 0.700 & 0.921 & 1.184 & 0.237 \\
Networking Capability & 0.933 & 0.699 & 0.926 & 10.503 & 0.000 \\
Finance & 0.941 & 0.697 & 0.867 & 6.600 & 0.000 \\
Non-Finance & 0.900 & 0.601 & 0.828 & 2.510 & 0.012 \\
\hline
\end{tabular}

Note: CR: Construct Reliability, AVE: Average Variances Extractions,

The MM illustrates the factor loadings, CR, AVE, t-statistics and p-values in the reflective level. Factor loading indicates seven items that are greater than 0.65 and closer to 0.7 . CR values were recorded as 0.942 , and 0.862 , as the maximum and the minimum respectively indicating the internal consistency of the reliability. Convergent validity illustrates AVE values greater than 0.5 for all dimensions which fulfill the threshold criteria. All Alpha values of the reliability were above 0.786 . T-statistics and $p$ values demonstrated indicator validity and significance of path coefficient at a satisfactory level except for the risk-taking which showed 1.184 and 0.237 respectively.

\subsection{Discriminant Validity}

The reflective model measured the discriminant validity too which illustrates that the AVE is higher than the Squared Interconstruct Correlation (SIC) values. The discriminant validity is shown in the matrix, and the square root of the AVE of each construct need to be higher than its highest correlation with any other construct (Fornell \& Larcker, 1981). Table 4 indicates the square root of the AVE in the form of a diagonal line with the relevant values highlighted.

Table 4: The Values in the Squared Inter-Construct Correlation

\begin{tabular}{|lllllllllll|}
\hline & Atti & ED & Fin & Inno & Know & NFin & Net & Pro & Risk & SK \\
Atti & $\mathbf{0 . 7 3 7}$ & & & & & & & & & \\
ED & 0.188 & $\mathbf{0 . 8 5 5}$ & & & & & & & & \\
Fin & 0.255 & 0.272 & $\mathbf{0 . 7 7 6}$ & & & & & & & \\
Inno & 0.291 & 0.453 & 0.162 & $\mathbf{0 . 8 6 9}$ & & & & & & \\
Know & 0.401 & 0.427 & 0.299 & 0.658 & $\mathbf{0 . 7 3 2}$ & & & & & \\
NFin & 0.275 & 0.454 & 0.114 & 0.677 & 0.708 & $\mathbf{0 . 7 3 5}$ & & & & \\
Net & 0.403 & 0.320 & 0.256 & 0.488 & 0.554 & 0.633 & $\mathbf{0 . 8 3 5}$ & & & \\
Pro & 0.328 & 0.450 & 0.259 & 0.663 & 0.668 & 0.684 & 0.603 & $\mathbf{0 . 8 3 6}$ & & \\
Risk & 0.076 & 0.057 & 0.174 & 0.111 & 0.198 & 0.101 & 0.073 & 0.109 & $\mathbf{0 . 8 3 6}$ & \\
SK & 0.654 & 0.381 & 0.238 & 0.468 & 0.500 & 0.430 & 0.522 & 0.438 & 0.126 & $\mathbf{0 . 7 8 3}$ \\
\hline
\end{tabular}

Note: Atti: Attitudes, ED: Entrepreneurship Desire, Fin: Finance, Inno: Innovation, Know: Knowledge, NFin: Non Finance, Net: Networking Capability, Pro: Proactiveness, Risk: Risk-taking, SK: Skills

This table explained that the validity of the variables was sufficient to evaluate BP. All dimensions were considered for further analysis giving attention to all the variables which shows a similar value.

\subsection{Relationship Between Dimensions of EO and BP}

EO comprises entrepreneurial desire, innovativeness, proactiveness, risk-taking and networking capability which are the selected dimensions for this study. The relationships between the dimensions and BP are shown in figure 2 below. 
Figure 2: The Relationships Between Entrepreneurial Orientation and Business Performance

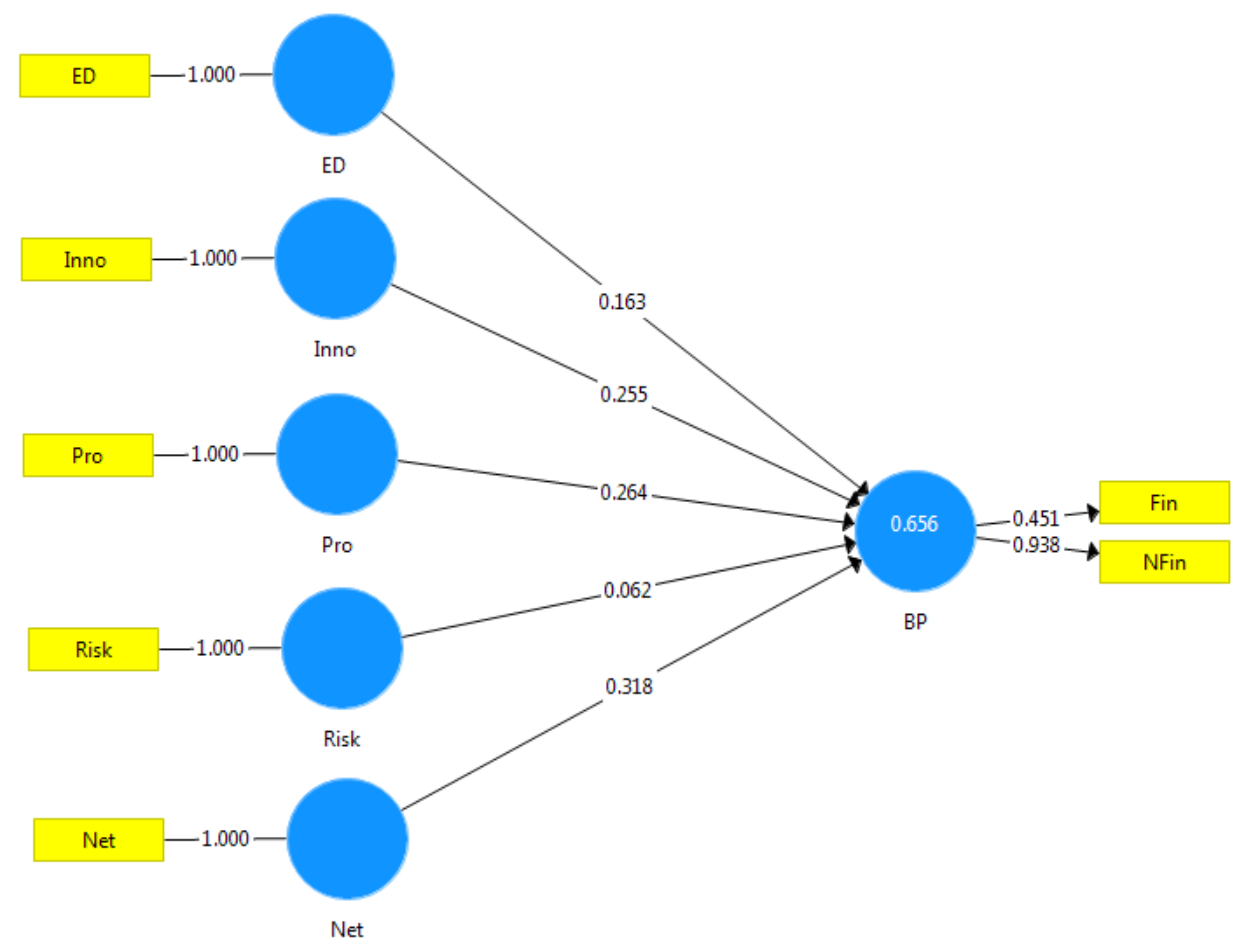

The hypothesized relationships between the dimensions of EO and BP are illustrated in the above figure. The path coefficient shows standardized values for the relationship that exists between BP and the three dimensions; Innovativeness, Proactiveness and Networking. These values specified strong positive relationships which are statistically significant while the path coefficient of ED and BP indicated values very close to a statistically significant level. The path coefficient of Risk-taking and BP demonstrated a positive relationship but statistically insignificant level. Although there was an insignificant relationship between risk-taking and $\mathrm{BP}$, it was decided to continue further analysis with five dimensions since Risk-taking is one of the significant dimensions of EO base on the information in the literature.

The coefficient values, mean, standard deviation, t-statistics and p-values are illustrated in Table 5 indicating the relationship between dimensions of EO and BP.

Table 5: Dimensions of Entrepreneurial Orientation and Business Performance

\begin{tabular}{lccccc}
\hline & Original Sample (O) & Sample Mean (M) & STDEV & $\begin{array}{c}\text { T Statistics } \\
(\mid \text { OO/STDEV|) }\end{array}$ & P Values \\
\hline ED -> BP & 0.163 & 0.160 & 0.084 & 1.930 & 0.054 \\
Inno -> BP & 0.255 & 0.273 & 0.092 & 2.774 & 0.006 \\
Net -> BP & 0.318 & 0.319 & 0.061 & 5.204 & 0.000 \\
Pro - > BP & 0.264 & 0.253 & 0.095 & 2.782 & 0.006 \\
Risk -> BP & 0.062 & 0.060 & 0.063 & 0.977 & 0.329 \\
\hline
\end{tabular}

Note: STDEV: Standard Deviation 
The above table exhibits the five relationships that exist between dimensions of EO and BP. Hence, it is clear that only four dimensions specified a statistically significant link. Since the relationship between Risk-taking and BP is insignificant due to the tstatistics value of 0.977 which should be higher than 1.96 and $p$ - the value of 0.329 which should be less than 0.05 .

\subsection{Hypotheses Testing}

It is an attempt to investigate how dimensions of EO affect business performance of graduate entrepreneurs in the USJ. In order to achieve this, the present study explores the relationships between the five selected dimensions of EO and BP among graduate entrepreneurs in USJ. Accordingly, the five hypotheses that were created as $\mathrm{H} 1$ to $\mathrm{H} 5$ based on the five dimensions representing the EO construct were examined.

\section{$H_{1}:$ There is a relationship between Entrepreneurial Desire and business performance}

Hypothesis one lay emphasis on the association between entrepreneurial desire (ED) and BP. As shown in table 5, the path coefficient value of 0.163 depicts a positive relationship between ED and BP. Further, it indicates the at-statistics value of 1.93 and a $p$-value of 0.05 which should be more than the accepted level of 1.96 and less than the 0.05 respectively. The $R^{2}$ is demonstrated as 0.254 which indicates 25 per cent of regression, resulting in a functional link between Entrepreneurship Desire and BP and the relationships between these two constructs were confirmed. This result is compatible with previous research (Bigliardi, 2013; Taatila, 2012) and several research studies (Al Ansari, Pervan \& Xu, 2013; Friedman, Aziz, Keles \& Sayfullin, 2012; Pratono et al., 2013) showed that entrepreneurial desire and BP has a direct relationship. Hence, the relationship between Entrepreneurial Desire and BP was considered to be statistically significant.

\section{$\mathrm{H}_{2}$ : There is a relationship between Innovativeness and Business Performance}

Hypothesis two states the relationship between innovativeness (Inno) and BP. The connection between Innovativeness and BP is demonstrated by the path coefficient of 0.255 as indicated in table 5 . This reveals a positive relationship between the two variables. The results also show that $t$-statistics value was 2.77 which should be more than 1.96 and the $p$-value was 0.006 which should be less than 0.05 . A 46 per cent of regression level is depicted by the $R^{2}$ value which is 0.461 demonstrating a good impact of Innovativeness on business performance. Hence the relationships of these two constructs were confirmed, and previous research (Al-Ansari, 2014; Arham, 2014; Ofem, 2014; Radipere, 2014) to is in alignment with this finding. The link between innovativeness and BP were resulting in a direct relationship in many research studies (Soininen, 2013; Kaunda, 2012).

\section{$\mathrm{H}_{3}$ : There is a relationship between Proactiveness and Business Performance}

The relationship between Proactiveness (Pro) and Business Performance (BP) is demonstrated by hypothesis three. As explained in table 5 positive relationship is indicated between Proactiveness and BP by having a path coefficient value of 0.264 . The $t-$ statistics value was 5.204 while $p$-value was 0.001 which should be more than 1.96 and less than 0.05 respectively. The percentage of regression is 50 where the $R^{2}$ value is 0.497 which represents a good impact of proactiveness on business performance, and the relationships between these two constructs can be confirmed. Earlier research (Gamage, 2014; Ofem, 2014) is comparable with this finding. It is also seen that in many research proactiveness demonstrated a direct relationship with BP (Soininen, 2013).

\section{$\mathrm{H}_{4}$ : There is a relationship between networking capability and business performance}

Hypothesis four highlights the relationship between networking capability (Net) and BP. The Table 5 indicates the path coefficient value of 0.318 confirming the positive relationship between networking capability and BP. It can also be seen that the t-statistics value is 2.78 which should be more than 1.96 and the $p$-value is 0.006 which should be less than 0.05 . The $R^{2}$ value of 0.432 depicts 43 percentage of regression representing a good impact of networking capability on business performance. Hence, the relationships between these two constructs can be confirmed while previous research (Soininen et al., 2013; Zhang et al., 2015) is in agreement with these results. Several other researches too proved a direct relationship between networking capability and BP (Palalic \& Busatlic, 2015; Su, Xie \& Wang, 2013).

\section{H5: There is a relationship between Risk-taking (Risk) and Business Performance.}

Hypotheses five specifies the relationship between Risk-taking (Risk) and BP. Table 5 demonstrates the path coefficient value of 0.062 indicating a positive relationship between Risk-taking and BP. Also, $t$ value is 0.977 along with a $p$-value of 0.329 which should be higher than 1.96 and less than 0.05 respectively. The $R^{2}$ value is denoted as 0.037 representing 3 per cent of regression which proves a weak relationship between Risk-taking and BP. Hence the relationships between these two constructs can be confirmed while these results are by research conducted earlier (Wejetunga, 2014, Wickramaratne, 2014). When the 
links between Risk-taking with BP is taken into consideration, several research findings showed different relationships indicating significant and insignificant links (Friedman, Aziz, Keles \& Sayfullin, 2012; Radipere, 2014; Ofem, 2014). This study indicated a statistically insignificant relationship between these two variables which highlights that greater implementation of Risk-taking is not associated with BP. Although there is no sufficient evidence to prove that Risk-taking significantly affects BP in the present study this finding is compatible with the results of a study carried out in Sri Lanka (Wijetunga, 2014). The findings of that study revealed that entrepreneurs who are not keen to take the risk could lead to difficulties in their effort to achieve the objectives of their businesses which result in growth uncertainty. The five hypotheses were tested based on the objective of the study, and the summarised details are shown in Table 6.

Table 6: Summary of Hypothesis Testing on Dimensions of EO and BP

\begin{tabular}{|c|c|c|c|c|c|}
\hline Path & Hypothesis & Path Coefficient & T Statistics & P Values & Support \\
\hline $\begin{array}{l}\text { H1: } \\
\text { ED-> BP }\end{array}$ & $\begin{array}{l}\text { There is a relationship between ED and } \\
\text { BP }\end{array}$ & 0.163 & 1.930 & 0.054 & Yes \\
\hline $\begin{array}{l}\text { H2: } \\
\text { Inno->BP }\end{array}$ & $\begin{array}{l}\text { There is a relationship between } \\
\text { Innovativeness and BP }\end{array}$ & 0.255 & 2.774 & 0.006 & Yes \\
\hline $\begin{array}{l}\text { H3: } \\
\text { Pro-> BP }\end{array}$ & $\begin{array}{l}\text { There is a relationship between } \\
\text { Proactiveness and BP }\end{array}$ & 0.318 & 5.204 & 0.000 & Yes \\
\hline $\begin{array}{l}\text { H4: } \\
\text { Net-> BP }\end{array}$ & $\begin{array}{l}\text { There is a relationship between } \\
\text { Networking capability and BP }\end{array}$ & 0.264 & 2.782 & 0.006 & Yes \\
\hline $\begin{array}{l}\text { H5: } \\
\text { Rsk-> BP }\end{array}$ & $\begin{array}{l}\text { There is a relationship between Risk- } \\
\text { taking and BP }\end{array}$ & 0.062 & 0.977 & 0.329 & No \\
\hline
\end{tabular}

All figures shown in the above table demonstrate the relationship between each dimension of EO and BP. Four hypotheses except the hypothesis 5, supported and proved that the relationship between Risk-taking and BP are statistically significant. Hence the entrepreneurial desire, innovativeness, proactiveness and networking are proved to be advantageous to business development. Further, the graduate entrepreneurs have the perception that entrepreneurial learning environment along with EO in the university system enhanced their strength to manage businesses.

The findings of this study would summarise management implications and suggest essential recommendations to the university system focusing on BP of graduate entrepreneurs of USJ in Sri Lanka. The study investigated the effect of five EO dimensions on $\mathrm{BP}$ among graduate entrepreneurs. The component of EO plays a dominant role in the university system where the graduates who intend to start new ventures and exhibit entrepreneurial action in an organisation. Hence there is a new trend among the graduates to have an increased awareness of EO which leads to achieving the above mindset. Entrepreneurial Desire, Innovativeness, Proactiveness, Risk-taking and Networking Capability are the five dimensions of EO that are directly relevant to BP of graduates and have a unique relationship. The findings of this study enhance the EO construct empirically concerning BP.

The desire for entrepreneurship among graduates facilitates the ability to manage a venture successfully, and they desire to carry out somewhat entrepreneurial when managing the businesses. Presently, the entrepreneurship desire has shown extra attention in the literature and highlighted that "if no matter which relics continuous the whole time in the journey of entrepreneurship, that is the desire of entrepreneurship" (McMullen \& Dimov 2013). Since business needs a more significant commitment along with time for work satisfaction, budding entrepreneurs with an inclination for development are expected to be steered by a desire to a large extent (Douglas \& Douglas, 2013). Based on the information, it is prominent that in the presence of entrepreneurial desire, any study on the construct of EO would be completed ardently.

Further, it also enumerates that if the graduate entrepreneurs show a more significant interest in innovativeness, they tend to perform better than others who do not practice innovation (Belgacem, 2015). This has been proved in many empirical studies in the literature (Hove \& Goliath, 2016; Kraus, 2012; Belgacem, 2015; Duru, Ehidiamhen \& Chijioke, 2018). In contemporary society, it can be seen that continuous rapid modifications and implementation of proper new ideas and novelty which could provide vital engagement for obtaining competitive advantage are one of the reasons for applying innovativeness in the entrepreneurial businesses. Deficiency of the innovativeness in any business organisation could result in pessimism in future development and has a direct effect on the research implications too.

Similarly, when the graduate entrepreneurs exhibit proactiveness to foresee changes that demand improved productivity, it increases their efficiency and effectiveness. The dimension of proactiveness of EO which implies the future seeing nature of conducting initial steps in expectation of potential requirements at present or promising markets to achieve benefits over 
competitors (Wiklund \& Shepherd 2005) is exposed by many empirical studies (Hove \& Goliath, 2016; Kraus, 2012; Belgacem, 2015; Duru, Ehidiamhen \& Chijioke, 2018).

Further, Networking Capability of graduate entrepreneurs indicated a higher level of the interrelationship between stakeholders and enhanced BP. Network capability which is the ability to establish, maintain, and leverage ties, contacts and connections together implies the importance of the concept in relation to the businesses and used as a measure of the EO construct in numerous empirical research (Taatila, 2012; Rutten \& Boekema, 2007; Jensen \& Greve, 2002; Wright Hoskisson, Filatotchev, \& Buck, 1998). Earlier research points out that the link, networking capability has with BP is not fully stated, and it is required to be exposed, and lack of networking capability in a business venture can lead to difficulties of growth (Mu, 2013). The significance of networks in the survival and accomplishment of individual businesses has been an important point that was illustrated in few types of research showing a little attention (Olm, Carsrud \& Alvey, 1988; Aldrich \& Zimmer 1989; Rosa \& Hamilton, 1994; Baines $\&$ Wheelock, 1998). Hence it is worthwhile to investigate the networking capabilities of the entrepreneurs and its effect on EO.

However, the assessment revealed that graduate entrepreneurs of this study had been engaged in Risk taking very rarely, about EO. Further, it can be seen that risk-taking as a dimension of EO is used in numerous studies in the literature with different disciplines and highlighting varied results (Covin \& Slevin 1989; Naman \& Slevin 1993; Zahra \& Garvis 2000; Kemelgor 2002; 2005, Hove \& Goliath, 2016; Kraus, 2012; Belgacem,2015; Duru, Ehidiamhen \& Chijioke, 2018). Further, it is vital to note that having the risk-taking dimension in measurements, provides evidence on the EO towards the incorporation of uncertainty to a massive fear of it (Kraus et al., 2012). This indicates a high level of EO, and it believes that risk-taking in business, can be suggested as dreams to be the owner-managers who are willing to become rich and develop a market through implementing new ideas (Frank, Kessler \& Fink, 2010). However some studies conducted by many researchers proved that risk-taking was not positively related to BP (Swierczek \& Ha, 2003) Besides, results similar to findings of this study is indicated in Nigeria where risktaking had a positive and insignificant relationship with BP (Duru, Ehidiamhen1 \& Chijioke, 2018). Additionally, one of the studies done in South Africa did not show a significant positive association between risk-taking and performance of young-adult owned small businesses (Hove \& Goliath, 2016). This nature of diverse results indicates a need for more research in the future to assess risk-taking dimension.

Hence the above findings highlighted that the graduate entrepreneurs prioritised the need to improve their capabilities to run their businesses successfully through developing EO. Significant components of this study are considered with the aim of focusing on the future exploration of new research filling the existing knowledge gap. Enhancing these competencies to begin a novel start-up or run existing businesses are significant intentions of the study. It opens the door to investigate the impact of individual EO and its effect on BP. However, for the new ventures to be successful, it is required that businesses which are run by the graduate entrepreneurs are entrepreneurially oriented (Hove \& Goliath, 2016). Therefore, the primary purpose of a successful business is thought to be, to study these objectives and apply them to engaging EO studies about BP.

\section{CONCLUSION}

In ending, it is evident from the literature that graduate entrepreneurs exhibit insufficient levels of desire for entrepreneurship, lack of creativity and innovative actions, lethargy towards futuristic planning, risk adverse behaviour and negligence of network links which remain unreciprocated. Investigating the output of EO of graduates about the dimensions of entrepreneurial desire, innovativeness, proactiveness, risk-taking and networking capability are considered as most important among many other components that serve the purpose. It is clear that all the dimensions of individual EO considered in this study enhance the BP positively. However, all dimensions except risk-taking showed the association as statistically significant implying that more detailed and empirical research is required to investigate the impact of risk-taking on BP in the future too. The graduate entrepreneurs reiterated the requirement to enhance their abilities to run their businesses successfully by developing EO which indicates the importance of individual EO.

It is therefore vital that academia within the university system, entrepreneurs as change agents of a country and responsible policymakers about the government and non-government institutes be focused on sustainable development with required EO mindset for economic advancement. 


\section{REFERENCES}

Ajzen, I. (2002). Perceived behavioral control. Self-efficacy, the locus of control, and planned behaviour. Journal of applied social psychology, 32(4) 665-683: DOI: 10.1111/j.1559-1816.2002.tb00236.x.

Al-ansari, Y. D. Y. (2014). Innovation practices as a path to business growth performance: A study of small and medium-sized firms in the emerging UAE market (PhD dissertation). Southern Cross University, Lismore, NSW.

Al-Ansari, Y., Pervan, S., Xu, J. (2013). Innovation and business performance of SMEs: the case of Dubai. Education, Business and Society: Contemporary Middle Eastern Issues, 6(3/4), 162-180.

Alarape, A. A. (2013). Entrepreneurial orientation and the growth performance of small and medium enterprises in Southwestern Nigeria. Journal of Small Business \& Entrepreneurship, 26(6), 553-577. https://doi.org/10.1080/08276331.2014.892308.

Aldrich, H., Zimmer, C. (1986). Entrepreneurship through social networks. In D. L. Sexton, and R.W. Similar (Eds), The Art and Science of Entrepreneurship, Cambridge, MA: Ballinger 3-23

Al-Nuiami, M., Idris, W. M. S., Al-Ferokh, F. A., Hussein, M. (2014). An environmental turbulence and innovation performance in five-star hotels in Jordan. Empirical Study of the Moderator Effect of Entrepreneurial Orientation on the Relationship between environmental turbulence and innovation performance in five-star hotels in Jordan. International Journal of Business Administration, 5(2), 111-125.

Amolo, J., Migiro, S. O. (2014). Entrepreneurship complexity : Salient features of entrepreneurship. African Journal of Business Management, 8(19), 832-841. http://doi.org/10.5897/AJBM2014.7442.

Arham, A. F. (2014). The relationship between leadership behaviour, entrepreneurial orientation and organisational performance in Malaysian small and medium enterprises (Doctoral Thesis). RMIT University. Melbourne, Australia. http://researchbank.rmit.edu.au/view/rmit:160765.

Azevedo, R. (2008). The role of self-regulation in learning about science with hypermedia. In D. Robinson \& G. Schraw (Eds.), Recent innovations in educational technology that facilitate student learning. Charlotte, NC: Information Age Publishing.

Baines, S., Wheelock, J. (1998). Working for each other: Gender, the household and micro-business survival and growth. International Small Business Journal, 17(1), 16-35.

Belgacem, B. (2015). Entrepreneurial orientation and firms' performance: The case of Tunisian companies. International Journal of Economics, Commerce and Management, 3(3), 1-15.

Beliaeva, T. (2014). Antecedents and performance outcomes of entrepreneurial orientation: A comparative cross-country study (Master's Thesis). Saint- Petersburg - Lappeenranta.University St. Petursberg, Russia.

Bigliardi, B. (2013). The effect of innovation on financial performance: A research study involving SMEs. Innovation. Management, Policy \& Practice, 15(2), 245-256. http://doi.org/10.5172/impp.2013.15.2.245.

Böcskei, E., Fekete, H. (2012). Business performance measurement in the light of recent decades. The role of performance management, 3(1), 15 .

Bolton, D. L., and Lane, M. D. (2012). Individual entrepreneurial orientation: Development of a measurement instrument. Education+ Training, $54(2 / 3), 219-233$.

Boso, N., Story, V. M., Cadogan, J. W. (2013). Entrepreneurial orientation, market orientation, network ties, and performance: Study of entrepreneurial firms in a developing economy. Journal of Business Venturing, 28(6), 708-727.

Botchkarev. A. (2015). Estimating the accuracy of the return on investment (ROI) performance evaluations. Interdisciplinary Journal of Information, Knowledge and Management, 10, 217-233. http://www.ijikm.org/Volume10/IJIKMv10p217-233Bchkarev2027.pdf.

Buckley, P., Park, B. (2014). Realized absorptive capacity, technology acquisition and performance in international collaborative formations: an empirical examination in the Korean context, Asia Pacific Business Review 20(1) 109-135.

Clarkson, M. B. E. (1995). A stakeholder framework for analyzing and evaluating corporate social performance. Academy of Management Review, 20, 92-117.

Covin, J. G., Slevin, D. P. (1986). The development and testing of an organizational-level entrepreneurship scale. In R. Ronstadt, J. A. Hornaday, R. Peterson and K. H. Vesper (eds), Frontiers of Entrepreneurship Research 1986. Center for Entrepreneurial Studies, Wellesley, MA, Babson College, pp. 628-639.

Covin, J. G., Slevin, D. P. (1989). The development and testing of an organizational-level entrepreneurship scale. In R. Ronstadt, J. A. Hornaday, R. Peterson and K. H. Vesper (eds), Frontiers of Entrepreneurship Research (pp 1-27). Wellesley, MA: Center for Entrepreneurial Studies, Babson College. 
Covin, J. G., Green, K. M., Slevin, D. P. (2006). Strategic process effects on the entrepreneurial orientation-sales growth rate relationship. Entrepreneurship theory and practice, 30(1), 57-81. https://doi.org/10.1177/104225879101600102

Donaldson, T., L. Preston. (1995). The stakeholder theory of the corporation-Concepts, evidence, and implications. Academy of Management Review, 20(1), 65-91.

Douglas, P., Douglas, M. (2013). Risk and blame. London: Routledge.

Duru, I. U., Ehidiamhen, P. O., Chijioke, A. N. J. (2018). Role of entrepreneurial orientation in the performance of small and medium enterprises: evidence from capital territory, Abija, Nigeria. Asian Journal of Economics, Business and Accounting, 6(1), 1-21. DOI:10.9734/AJEBA/2018/39748

Elenurm, T. (2012). Entrepreneurial orientations of business students and entrepreneurs. Baltic Journal of Management, 7(2), $217-231$.

Engström, P., McKelvie, A.(2016). Financial literacy and firm performance in informal economy firms in Ecuador. Frontiers of Entrepreneurship Research, 36(16), Article 8. https://digitalknowledge.babson.edu/fer/vol36/iss16/8.

Fani, A. (2015). The relationship between knowledge management and organisational learning within the middle and senior managers of Iranian public organisation. Information and Knowledge Management, 5(6), 102-213.

Fornell, C., Larcker, D. F. (1981). Evaluating structural equation models with unobservable variables and measurement error. Journal of Marketing Research, 18(1), 39-50.

Forth, J., Bryson, A. (2018). The impact of management practices on SME performance. IZA Discussion Paper No. 11399. Available at SSRN: https://ssrn.com/abstract=3153363

Frank, H., Kessler, A., Fink, M. (2010). Entrepreneurial orientation and business performance: A replication study. Schmalenbach Business Review, 62(2), 175-199.

Freeman, R. E, Reed, D. L. (1983). Stockholders and stakeholders: A new perspective on corporate governance. California Management Review, 25(3), 88-106.

Friedman, B. A., Aziz, N., Keles, I., Sayfullin, S. (2012). Predictors of students' desire to be an entrepreneur: Kyrgyzstan, Georgia and the United States. Eurasian Journal of Business and Economics, 5(9), 129 - 140.

Gamage, B. N. (2014). Entrepreneurship orientation, business performance appraisal of small and medium-scale enterprises: Reference to Hambanthota district, Sri Lanka. International Journal of Marketing, Financial Services and Management Research, 03(12), $174-185$.

Gardner, P. L. (1998). Measuring attitudes to science: Unidimensionality and internal consistency revisited. Research in Science Education, 25(3), 283-289. doi:10.1007/BF02357402

Gerba, Y. T., Viswanadham, P. (2016). Performance measurement of small-scale enterprises: Review of the theoretical and empirical literature. International Journal of Applied Research, 2(3): 531-535

Goktan, A. B., Gupta, V. K. (2015). Sex, gender, and individual entrepreneurial orientation: evidence from four countries. International Entrepreneurship and Management Journal, 11(1), 95-112. DOI: 10.1007/s11365-013-0278-z.

Gupta, V. K., Batra, S. (2015). Entrepreneurial orientation and firm performance in Indian SMEs: Universal and contingency perspectives. International Small Business Journal, 34(5), 660-682. DOI:10.1177/0266242615577708.

Haid, D. (2004). Corporate Entrepreneurship im strategischen Management: Ansatz zur Implementierung des Unternehmertums im Unternehmen. Springer-Verlag.

Haider, S. H., Asad, M., Fatima, M., Abidin, R. Z. U. (2017). Microfinance and performance of micro and small enterprises; Does Training has an impact. Journal of Entrepreneurship and Business Innovation, 4(1).

Hair, J. F., Ringle, C. M., Sarstedt, M. (2013). Partial least squares structural equation modeling: rigorous applications, better results and higher acceptance. Long Range Planning, 46(1/2),1-12.

Hamidon, S. (2012). Entrepreneurship development in Malaysian higher education: Challenges, opportunities and way forward. Hangzhou: UNESCO-APEID.

Hanafiah, M. H., Yousaf, U., Hashim, N. A., (2016). Entrepreneurs' intention to invest in current business: An empirical study of Malaysian SME entrepreneurs. Malaysian Journal of Society and Space, 12(2), 119-131.

Harms, R. (2004). Befunde in der Literatur zu Rapide wachsenden Unternehmen. In Entrepreneurship in Wachstumsunternehmen (pp. 9-29). Deutscher Universitätsverlag

Henseler, J., Chin, W. W. (2010). A comparison of approaches for the analysis of interaction effects between latent variables using partial least squares path modeling. Structural Equation Modeling, 17(1), 82-109. 
Hove, T. M. M., Goliath, J. E. (2016). The entrepreneurial orientation and business performance relationship: A study of young adult-owned small businesses. 28th Annual Conference of the Southern African Institute of Management Scientists, South Africa. https://www.researchgate.net/publication/317259073.

Hudson M. A., Smart A., Bourne M. (2001). Theory and practice in SME performance measurement systems. International Journal of Operations \& Production Management, 21(8), 1096-1115.

Hult, G. T. M., Hurley, R. F., Knight, G. A. (2004). Innovativeness: Its antecedents and impact on business performance. Industrial marketing management, 33(5), 429-438.

Ibrahim, N. A., Lucky, E. O. I. (2014). The relationship between entrepreneurial orientation, entrepreneurial skills, environmental factor and entrepreneurial intention among Nigerian students in UUM. Entrepreneurship and Innovation Management Journal, 2(4), 203-213.

Jensen, J. I., Greve, A. (2002). Does the degree of redundancy in social networks influence the success of business start-ups? International Journal of Entrepreneurial Behavior \& Research 8(5), 254-267.

Kaplan, R. S., Norton, D. P. (1996). Linking the balanced scorecard to strategy. California Management Review, 39(1), 53-79. https://doi.org/10.2307/41165876.

Karyotakis, K. M., Moustakis, V. S. (2016). Organizational factors, organizational culture, job satisfaction and entrepreneurial orientation in public administration. The European Journal of Applied Economics, 13(1), 47-59.

Kaunda, C. M. (2012). Entrepreneurial orientation, the age of owner and small business performance in Johannesburg (Unpublished research report). Faculty of Commerce, Law and Management, University of the Witwatersrand.

Kemelgor, B. H. (2002). A comparative analysis of corporate entrepreneurial orientation between selected firms in the Netherlands and the USA. Entrepreneurship \& Regional Development, 14(1), 67-87. DOI: 10.1080/08985620110087023

King, P. J., Roberts, N. C. R. (1987). Policy entrepreneurs: Catalysts for policy innovation. Journal of State Government, 60, 172-179.

Kline, R. B. (2015). Principles and practice of structural equation modelling. Guilford publications, New York.

Koe, W. L. (2016). The relationship between Individual Entrepreneurial Orientation (IEO) and entrepreneurial intention. Journal of Global Entrepreneurship Research, 6(1), 13.

Koe, W. L., Majid, I. A. (2013). Sustainable entrepreneurship among small and medium enterprises (SMEs) in Malaysia. International Journal, 2(4), 286-290.

Kollmann, T., Christofor, J., Kuckertz, A. (2007). Explaining proper entrepreneurial orientation: Conceptualisation of a cross-cultural research framework. International Journal of Entrepreneurship and Small Business, 4(3), 325-340.

Kraus, S. (2013). The role of entrepreneurial orientation in service firms: empirical evidence from Austria. The Service Industries Journal, 33(5), 427-444.

Kraus, S., Burtscher, J., Vallaster, C., Angerer, M. (2018). Sustainable entrepreneurship orientation: A reflection on status-quo research on factors facilitating responsible managerial practices. Sustainable, 10(2), 444- 465. https://doi.org/10.3390/su10020444.

Kropp, F., Lindsay, N. J., Shoham, A. (2008). Entrepreneurial orientation and international entrepreneurial business venture startup. International Journal of Entrepreneurial Behaviour\& Research, 14(2), 102-117. http://doi.org/10.1108/13552550810863080

Krueger, N. F. (1993). The impact of prior entrepreneurial exposure on perceptions of new venture feasibility and desirability, Entrepreneurship: Theory and Practice 18(1) 5-21.

Lackeus, M. (2018). "What is value?" A framework for analyzing and facilitating entrepreneurial value. United, 41, 10-28. DOI: 10.18261/issn.1893-8981-2018-01-02.

Laukkanen, T., Nagy, G., Hirvonen, S., Reijonen, H., Pasanen, M. (2013). The effect of strategic orientations on business performance in SMEs: a multi-group analysis comparing Hungary and Finland. International Marketing Review, 30(6), 510-535.

Lee, S. M., Lim, S. B., Pathak, R. D. (2011). Culture and entrepreneurial orientation: A multi-country study. International Entrepreneurship and Management Journal, 7(1): 1-15. (doi:10.1007/s11365-009-0117-4)

Lomberg, C., Urbig, D., Stöckmann, C., Marino, L. D., and Dickson, P. H., (2017). Entrepreneurial orientation: The dimensions' shared effects in explaining firm performance. Entrepreneurship Theory and Practice, 41(6), 973-998. http://dx.doi.org/10.1111/etap.12237.

Lumpkin, G. T., Dess, G. G. (1996). Clarifying the entrepreneurial orientation construct and link it to performance. The Academy of Management Review, 21(1), 135-172. 
Lumpkin, G. T., Dess, G. G. (2001). Linking two dimensions of entrepreneurial orientation to firm performance: The moderating role of environment and industry life cycle. Journal of Business Venturing, 16(5), 429-451. http://doi.org/10.1016/S0883-9026(00)00048-3.

Lumpkin, G. T., Dess, G. G. (2006). The effect of simplicity on the strategy performance relationship: a note. Journal of Management Studies, 43(7), 1583-1604.

Mahmood, R., Hanafi, N., (2013) Entrepreneurial orientation and business performance of women-owned small and medium enterprises in Malaysia: competitive advantage as a mediator International. Journal in Business and Social Sciences, 4(1), 82-90.

McMullen, J. S., Dimov, D. (2013). Time and the entrepreneurial journey: The problems and promise of studying entrepreneurship as a process. Journal of Management Studies, 50(8), 1481-1512.

Memon, A. A., Ting, H., Ramayah, T., Chuah, F., Cheah, J. (2017). A review of methodological misconceptions and guidelines related to the application of structural equation modelling: A Malaysian scenario. Journal of applied structural equation modelling, 1(1), 1-13.

Miller, D. (1983). The correlates of entrepreneurship in three types of firms. Management Sciences, 29(7), 770-790.

Mu, J. (2013). Networking capability, new venture performance and entrepreneurial rent. Journal of Research in Marketing and Entrepreneurship, 15(2), 101-123.

Naman, J. L., Slevin, D. P. (1993): Entrepreneurship and the concept of fit: A model and empirical tests. Strategic Management Journal, 14(2), 137-153.

Neely, A., Gregory, M., Platts, K. (1995) Performance measurement system design- A literature review and research agenda. International Journal of Operations \& Productions Management, 15(4), 80-116.

Ofem, B., (2014). Entrepreneurial orientation, collaborative networks and non-profit performance (PhD Dissertation). College of Business and Economics, University of Kentucky, Lexington, Kentucky, USA.

Olm, K. Carsrud, A., Alvey, L. (1988). The role of networks in new venture funding for the female entrepreneur: A continuing analysis. In B. Kirchhoff et al., eds., Frontiers of Entrepreneurship Research. Wellesley, MA: Babson College

Omisakin, O. M., Nakhid, C., Littrell, R., Verbitsky, J. (2016). Entrepreneurial orientation among migrants and small and medium enterprises. Journal of Business Administration Research, 5(1), 7. http://doi.org/10.5430/jbar.v5n1p7.

Palalic, R., Busatlic, S. (2015). Exploratory research on relationship between entrepreneurial orientation dimensions and business performance and growth of fast and slow growing small and medium enterprises in Bosnia and Herzegovina. International Journal of Business and Management, 10(2), 15-30. http://doi.org/10.5539/ijbm.v10n2p15.

Pratono, A. H., Tee, C. W., Syahchari, D. H., Nugraha, A. T., Mat, N. K. N., Fitri, H. (2013). The direct effect of entrepreneurial orientation and innovation success on firm performance. American Journal of Economics, 3(1), 1-6.

Radipere. (2015). Entrepreneurial orientation: A case of Gauteng province, South Africa. Foundations of Management, 7(1), 169-184.

Raimond, E. (2016). What difference does good monitoring \& evaluation make to world bank project performance? Washington DC: Independent Evaluation Group. World Bank. https://openknowledge.worldbank.org/handle/10986/24644 License: CC BY 3.0 IGO.

Rasli, A. Md., Khan, S. R., Malekifar, S., Jabeen, S. (2013). Factors affecting entrepreneurial Intention among graduate students of Universiti Teknologi Malaysia. International Journal of Business and Social Science, 4(2), 182-188.

Rauch, A., Wiklund, J., Lumpkin, G., Frese, M. (2009). Entrepreneurial orientation and business performance: An assessment of past research and suggestions for the future. Entrepreneurship Theory and Practice 33(3), 761-787.

Riquelme, H. E., Al Lanqawi, A. (2016). The desire that propels entrepreneurial intentions. Journal of Entrepreneurship, Management and Innovation, 12/2016(2), 123-150.

Robinson, S., Stubberud, H. A. (2014). Teaching creativity, teamwork and other soft skills for entrepreneurship. Journal of Entrepreneurship Education, 17.

Rolstadls, A. (1995). Performance management - A business process benchmarking approach. London: Chapman \& Hall.

Rosa, P., Hamilton, D. (1994). Gender and ownership in UK small firms. Entrepreneurship theory and practice, 18(3), 11-27.

Rutten, R., Boekema, F. (2007). The learning region: foundations, state of the art, and future, Cheltenham: Edward Elgar.

Salehia, M., Ghorbanib, B. (2011). A study of using financial and non-financial criteria in evaluating performance: Some evidence of Iran. Serbian Journal of Management, 6(1), 97-108.

Schepers, J., Voordeckers, W., Steijvers, T., Laveren, E. (2014). The entrepreneurial orientation-performance relationship in private family firms: the moderating role of socio-emotional wealth. Small Business Economics, 43(1), 39-55. 
Sekaran, U., Bougie, R., (2013). Research methods for business, A skill-building approach. 6th Edition. New York: Pearson.

Shogren, K. A., Dean, E., Griffin, C., Steveley, J., Sickles, R., Wehmeyer, M. L., Palmer, S. B. (2017). Promoting change in employment supports Impacts of a community-based change model. Journal of Vocational Rehabilitation, 47(1), 19-24.

Soininen, J. (2013). Entrepreneurial orientation in small and medium-sized enterprises during economic crisis (PhD Thesis). School of Business, Lappeenranta University of Technology, Finland.

Sok, P., Snell, L., Lee, W. J., Sok, K. M. (2017). Linking entrepreneurial orientation and small service firm performance through marketing resources and marketing capability. Journal of Service Theory and Practice, 27(1), 231-249. https://doi.org/10.1108/JSTP-01-2016-0001.

Sriprasert, P. (2013). The effect of entrepreneurial orientation on the success of community enterprise: a study of nakhonsithammarat, Thailand. International Proceedings of Economics, 59(33), 158- 162.

Su, Z., Xie, E., Wang, D., (2013). Entrepreneurial orientation, managerial networking and new venture performance in China. Journal of Small Business Management, 53(1), 228 - 248. https://doi.org/10.1111/jsbm.12069.

Swierczek, F. W., Ha, T. T. (2003). Entrepreneurial orientation, uncertainty avoidance and firm performance: an analysis of Thai and Vietnamese SMEs. The International Journal of Entrepreneurship and Innovation, 4(1), 46-58.

Taatila, V., Down, S. (2012). Measuring entrepreneurial orientation of university students. Education + Training, 54(8), 744-760. doi: $10.1108 / 00400911211274864$.

University Grants Commission of Sri Lanka, Strategic Management Plan 2013 - 2017, September 2015.

Van Doorn, S., Jansen, J. J., Van den Bosch, F. A., Volberda, H. W. (2013). Entrepreneurial orientation and firm performance: Drawing attention to the senior team. Journal of Product Innovation Management, 30(5), 821-836.

Venkatraman, N. (1997). Beyond outsourcing: Managing IT resources as a value center. Sloan Management Review, 38 (3), 51-64.

Vij, S., Bedi, H. S. (2012). Relationship between entrepreneurial orientation and business performance: A review of literatüre. The IUP Journal of Business Strategy, 9(3), 17-31.

Wang, C. L. (2008). Entrepreneurial orientation, learning orientation, and firm performance, entrepreneurship theory and practice. 32,(4), 635657, DOI: $10.1111 / \mathrm{j} .1540-6520.2008 .00246 . x$

Wedathanthrige, H. (2014). Personal competencies for innovation: A case study of small and medium enterprises of coir industry in the North Western Province of Sri Lanka. Ruhuna Journal of Management and Finance, 1(1), 15-24.

Weerakoon, C. (2014). Organizational determinants of entrepreneurial orientation: (With Reference to Small Scale ITBPO Firms in Sri Lanka). International Journal of Science and Research, 3(10):1240-1247.

Wijetunge, W., Pushpakumari, M. (2014). Entrepreneurial orientation and business performance of small and medium scale enterprises of Western Province in Sri Lanka. Kelaniya Journal of Management, 2(2), 51-67. http://doi.org/10.4038/kjm.v2i2.6550.

Wiklund, J., Shepherd, D. (2005). Entrepreneurial orientation and small business performance. A configurational approach. Journal of Business Venturing, 20(1), 71-91.

Wiklund, J., Shepherd, D. (2005). Entrepreneurial orientation and small business performance. A configurational approach, Journal of Business Venturing, 20(1), 71-91.

Wright, M., Hoskisson, R. E., Filatotchev, I., Buck, T. (1998). Revitalizing privatised Russian enterprises. Academy of Management Executive, 12(2), 74-5.

Zahra, S. A., Garvis, D. M. (2000). International corporate entrepreneurship and firm performance. The Moderating Effect of International Environmental Hostility. Journal of Business Venturing, 15(5-6): 469-492.

Zhang, X., Zhao, J., LeCun, Y. (2015). Character-level convolutional networks for text classification. Advances in Neural Information Processing Systems, $28,649-657$.

Zsido, K. E., Fenyves, V., (2015) Application of traditional and new approach methods in business performance measurement, Cross-Cultural Management Journal, 17(1), 51-57. 